Прегледни чланак

Máté I. Mohai

University of Pécs

Faculty of Law

mohai.mate@ajk.pte.hu

\title{
THE MEMORANDUM OF ASSOCIATION IN THE LIGHT OF THE PROVISIONS ON CONTRACTS OF THE HUNGARIAN CIVIL CODE
}

Abstract: The new Hungarian Civil Code regulates the memorandums of association of companies in its Third Book, while the Sixth Book contains the provisions of (other?) contracts. The memorandum of association is quite different from typical civil law contracts. Its most characteristic feature is that it establishes a legal entity. In most cases, the regulation of the memorandum of association is different from the provisions on contracts set out in the Civil Code, and there is no provision in the law according to which the latter should also be applied to the memorandum of association. But should they?

Keywords: memorandum of association, Hungarian Civil Code, Hungarian Companies Act, civil law contracts, exchange contracts

\section{BRIEF HISTORY OF THE MEMORANDUM OF ASSOCIATION}

In ancient Egypt, the existence of a memorandum of association is not yet clearly evincible. It was already present in Babylonian law, but it contained elements of agency and loan agreements. In ancient Greece, there was a form similar to the civil law association of today. In ancient law, contracts for the joint venture were primarily real contracts, which means, that they were created by transferring the assets needed to carry out the joint venture. Classical Roman law marked a breakthrough when the agreement between the parties was enough to conclude this contract. ${ }^{1}$

The lively commercial life in the Roman Empire and the accompanying jurisprudence have created a regulatory framework in the field of companies that

\footnotetext{
${ }^{1}$ István Sándor, „A társasági jog története Nyugat-Európában” Budapest 2005. 73-74.
} 
is still valid in its legal terms. In Roman law, we cannot speak of a separate company law, but among contract types, economic needs have brought about the emergence of different forms of societas as the Roman legal antecedents of partnerships. In addition to the societas, there were other forms similar to current corporate law forms, such as collegium, universitas, and some family law legal relationships that included the possibility of limited liability. An interesting phenomenon in Roman law was the societas publicanorum, organized to collect taxes. The latter was a societas in which the corporation's assets consisted of the private property of its members, but at the same time it was organized in the same way as the collegium. There are many references to the specific legal nature of societas publicanorum in many works dealing with the legal nature of companies, since this contractual form also had the characteristics of corporate organizations, playing an important role in the formation of a memorandum of association. ${ }^{2}$

\section{THE MEMORANDUM OF ASSOCIATION AND CIVIL LAW CONTRACTS}

According to contract theory, a company is no more than a group of contracts, that is, a bunch of contracts that regulate the relationships between the parties involved in the operation of the company. ${ }^{3}$ The importance of this theory in terms of corporate law is also significant because the current regulatory environment is very similar to its starting point and thus provides significant assistance in defining the current status and function of company law. The starting point of the logic of contract theory is that defining the content of all memorandums of association involves less or more costs. The primary function of company law is to minimize the costs associated with the contracts of economic operators. It can enforce this feature by creating general rules that govern aspects of the relationship between the parties that were not provided for by the parties. ${ }^{4}$

A significant part of civil law is constituted by the law of contracts. However, a memorandum of association is a very strange contract, quite different from typical civil law contracts. First and foremost, a memorandum of association is typically a contract of many parties - two parties are less frequent, the legal model models many members, and the number of members of bodies such as a public limited company can be hundreds of thousands or even millions. The "normal” contractual part of civil law does not say this expressis verbis, but it is quite clear

\footnotetext{
${ }^{2}$ György Schadl, „A társaságok és a társasági jog előzményei a római jogban.”, Acta Univ. Sapientiae, Legal Studies, 2/2013, 243-269.

${ }^{3}$ György Schadl, „A társaságok és a társasági jog fontosabb dogmatikai kérdéseinek elemzése.", Szeged 2011. 81.

${ }^{4}$ Ibid.
} 
that it plans the rules for contracts for two or up to three positions (seller-buyer, outsourcer-contractor, lessor-lessee, outsourcer-commissioner-third party). ${ }^{5}$

The vast majority of civil law contracts are exchange contracts, while memorandums of association are not. In exchange contracts, the parties are on different poles of a particular commodity relationship. Obviously, in the case of exchange contracts, cooperation between the parties is desirable; in the case of longer-term contractual relationships, cooperation can become permanent and institutional (main contracts for large investments), but since the parties are on the opposite side of the exchange of goods the cooperation is secondary to the conflict of interest stemming from the principal service (the main interest of the seller is the highest possible price and the main interest of the buyer is the lowest price possible in case of a contract of sale). At the same time, the essence of the memorandum of association is the organization of cooperation between the associates. The cooperation is also aimed at a market-oriented, businesslike undertaking. ${ }^{6}$

A memorandum of association is typically not a bilateral relationship. On the one hand, the company - typically - is a multi-person obligation, usually with more than two members. Even if there are two signatories to the contract, they are not providing services to each other. The legal status of the two is the same and they are no obligees or obligors. The characteristic of the exchange contract cannot prevail, because we cannot talk about the equivalence of services. One contractor can make up to a thousand times more valuable commitments, but even if the contributions are of equal value, because they are not paid to each other, they are not paid to the other party there is no classical value equation.

The memorandum of association differs from the exchange contracts regulated by the Civil Code not only because it does not have the characteristics of them, but also because it has features that are missing from these contracts. The most characteristic feature of a memorandum of association is that it establishes a legal entity. Its purpose is to create a new legal entity, the rights and obligations arising therefrom being predominantly on and against the new entity. Thus, the memorandum of association necessarily affects third parties to the extent that it is not an ancillary effect, but the core of the memorandum of association. ${ }^{7}$

The memorandum of association shows an interesting similarity with the contract concluded in favor of a third party, which is regulated in Section 6:136 of the Civil Code. However, the similarity is more interesting than substantive. In the case of such a contract, the service shall be provided not to the contractors but to the third party designated by them who has not participated in the contract. So there is a similarity with the memorandum of association. But even in the case of

\footnotetext{
${ }^{5}$ Tamás Sárközy, „A magyar társasági jog Európában”, Budapest 2001. 69-70.

${ }^{6}$ Tamás Sárközy, „Gazdasági státuszjog”, Budapest 2007. 128-129.

${ }^{7}$ Péter Miskolczi Bodnár, „A társasági szerződés sajátosságai a Ptk.-ban szabályozott szerződésekhez képest”, Gazdaság és Jog 2001/7-8, 27-37.
} 
a contract concluded in favor of a third party, the contractors are the rightholder and the debtor. The contracting party may demand that the service shall be performed for the benefit of the third party. In return for the service contracted for by the obligee, he is required to pay the obligor the consideration. Unlike the memorandum of association, the rightholder is therefore obliged to provide services to the debtor and not to the third party. Of course, in a contract concluded in favor of a third party, the parties do not express their will to establish a third party.

The rules of a contract concluded in favor of a third party cannot therefore be applied in the alternative to the memorandum of association. For a company, the rule that the third party shall be entitled to require performance of the service stipulated in his favor as of the date on which he receives notice of the contract from either party would not be applicable. It would also be incomprehensible to provide that, if the right to require performance of the service is declined by the third party, the service may be claimed by the party who concluded the contract in his favor. In my opinion, the company cannot decline to require the member to perform his contribution, since allowing such an option in the memorandum of association is precluded by Subsection (3) of Section 3:98 of the Civil Code and would therefore be null and void. This solution would obviously also violate the rights of the company's creditors, which is precluded by point b) Subsection (3) of Section 3:4 of the Civil Code. Obviously, a member, as a ,contractor in favor of the company", would not be entitled to claim the service, since in that case he would have to claim the service from himself. It would also be a problem to apply to the memorandum of association the rule that the obligor shall be entitled to enforce his objections to the contract in respect of the third person as well. Obviously, one member's objection to the other arising out of the memorandum of association cannot be enforced against the company.

\section{THE PROVISIONS ON CONTRACTS, AS THE UNDERLYING LAW?}

\section{III.1. Freedom of Contract and Duty to Cooperate}

In most cases, the regulation of the memorandum of association is different from the provisions on contracts set out in the Civil Code, and there is no provision in the law according to which the latter should also be applied to the memorandum of association. With respect to the memorandum of association, the Civil Code contains a number of mandatory provisions which restrict the freedom of the parties to conclude contracts (to choose the form of the contract) in several aspects.

For example, Subsection (1) of Section 6 of the Act LXXXVIII of 2014 on the Business of Insurance defines the form in which an insurer may be established 
in the territory of Hungary. The parties' freedom of choice in form thus does not extend to setting up an insurance company in the form of a limited liability company, for example. Instead of the freedom of choice, even Subsection (1) of Section 3:89 of the Civil Code states that a business association can only operate in the form of a general partnership, limited partnership, private limited-liability company or limited company. The law therefore does not allow private-law entities to set up companies - even of a non-standard type- at their discretion. There is even a requirement that the form of company (or its abbreviation, as described in the Civil Code) should appear in the name of the company, informing the people who are in contact with the company about the type of company they are dealing with. The Civil Code also restricts the freedom of contract with regard to the choice of the other party when, for example, it states that a general partnership may not be a member with unlimited liability in a business association [(2) 3:90 §].

Naturally, also in the case of companies, as regards relations between members, and between them and the company, and as regards the organizational structure and operational arrangements of the company, in the instrument of constitution the members may derogate from the provisions of the Civil Code relating to legal persons. But the members may not derogate from the provisions of the Civil Code a) if it is precluded by law; or b) where any derogation clearly violates the interests of the legal person's creditors, employees and minority members, or it is likely to prevent the exercise of effective supervision over legal persons.

Pursuant to Subsection (1) of Section 6:62 of the Civil Code, the parties shall be required to cooperate during preliminary negotiations, at the time of the conclusion and termination, and during the life of the memorandum of association, and shall be duty bound to communicate information to each other on circumstances relevant to the memorandum of association, which obligation to cooperate is also placed on the members by Subsection (3) of Section 3:88 of the Civil Code. This obligation extends not only to the other members but also to the organs of the company once the company is established.

\section{III.2. Conclusion of Contracts}

In my opinion, the provisions of the Civil Code concerning the conclusion of a contract must be applied properly. However, the application of general terms and conditions does not arise. In Hungary, it is not often the case that a preliminary memorandum of association is concluded, although it is interesting to note that German law distinguishes the pre-company (,Vorgesellschaft”) from the preliminary pre-company (,Vorgründungsgesellschaft" or "Vorvertragsgesellschaft”), when the founders commit themselves in a pre-contract to cooperate with each other to establish a company. Other cases of obligation to contract cannot be imagined in theory either. 
According to the Civil Code a contract may be concluded orally, in writing or by implication. The memorandum of association, however, shall be drawn up in a notarial document, or in a private document countersigned by a lawyer or the bar association legal counsel of a founder. The memorandum of association is therefore not just a written statement of the founders, which must be signed by the founders or their representative. It must be prepared with the assistance of a lawyer, partly to ensure legitimacy and partly to professionally regulate long-term company relationships.

The memorandum of association may be signed on behalf of a member by his representative holding an authorization fixed in an authentic instrument or in a private document representing conclusive evidence. The formality of the authorization is thus also satisfied by a ,simple" private document representing conclusive evidence. This is an exception to Subsection (2) of Section 6:15 of the Civil Code, which states that a power of attorney shall be subject to formal requirements as prescribed by law for making legal statements on the basis of a power of attorney. The power of attorney in a private document representing conclusive evidence authorizing to sign the memorandum of association does not need to be countersigned by a lawyer or the bar association legal counsel of a founder.

\section{III.3. The Invalidity and Ineffectiveness of the Memorandum of Association}

Directive (EU) 2017/1132 of the European Parliament and of the Council regulates the invalidity of a company. The overwhelming majority of the reasons listed are also grounds for invalidity of the memorandum of association. Because of the invalidity of the company the Hungarian Companies Act calls the proceedings listed in the Directive as actions for annulment of the formation of a company. Subsection (2) of Section 69 of the Companies Act states, that an action for nullity may be brought with respect to all types of companies only under the following grounds: a) the instrument of constitution had not been countersigned by a lawyer or by the founder's bar association legal counsel, or it was not drawn up in a notarial document; b) the instrument of constitution fails to state the company's corporate name, main business activity, subscribed capital, and/or the amount of the capital contributions of members; c) the company's scope of activities is unlawful; d) the incapacity of all the founding members, or failure to comply with the statutory provisions concerning the requirement of minimum number of members participating in the foundation of the company; e) failure to comply with the provisions concerning the minimum amount of capital to be paid up for private limited-liability companies and limited companies. The legal form of a company has no legal significance for external stakeholders, and the interests to be protected are considered to be the same for all company forms. 
The provisions on the nullity of contracts shall apply to the nullity of the memorandum of association of companies only insofar as the resolution on the registration of the company becomes final and enforceable. Pursuant to Subsection (1) of Section 69 of the Companies Act, a lawsuit may be filed for declaring the nullity of establishment of a registered company against the company within a six-month forfeit deadline following publication of the ruling ordering the company's registration in the Company Gazette at the general court where the company in question is established. Such lawsuit may be filed by the public prosecutor or by any party that is able to verify its legal interest. According to Subsection (3), the court shall order the company to take appropriate measures for having the reasons for nullity eliminated within the deadline prescribed. If the measures produce the results required, the court shall establish nullity and shall instruct the court of registry to take the measures specified in Subsection (2) of Section 66.

The fraudulent contract, which is detrimental to the creditor and which is regulated in Subsection (1) of Section 6:120 of the Civil Code, is a valid contract, but in certain circumstances it shall be ineffective with respect to the creditor. It follows from the foregoing that the restrictive provisions of Article 69 of the Companies Act cannot be interpreted broadly. Restrictions on litigation apply only to actions for a declaration of invalidity, since neither the grammatical nor the logical nor the systematic interpretation of the concept of invalidity can be attributed to the term ineffectiveness.

The registration of the company cannot be a legal obstacle for the creditor of the member (shareholder) of the company to take an action for ineffectiveness if the contribution of the member regulated in the memorandum of association or the amendment thereto withdraws the basis for the creditor's satisfaction, provided that the company was in bad faith.

The memorandum of association is a contract for consideration, which requires the members (founder) and shareholders of the company to make financial contributions - cash deposits or other contributions - in accordance with Section 3:9 of the Civil Code, and, in return, they acquire personal and other rights regarding the company. The company receiving the contribution, consisting of the members (founder) and shareholders, shall, in the case of bad faith, satisfy the claim of the member's creditor - based on a final judgment, which couldn't be enforced through legal enforcement - from the contribution of the member. If the acquiring company consists not only of natural persons but of legal persons, it's bad faith - knowing the nature of the contract as fraudulent - can be judged on the basis of a personal concentration between the debtor company and the company acquiring the assets. There is presumption regarding the bad faith of the company under certain circumstances, which is regulated in Subsection (2) of Section 120 of the Civil Code. 
Section 6:118 of the Civil Code regulates the contracts subject to consent or approval. However, in terms of content, this is different than when a company is created by registration with the company registry. The conclusion of the memorandum of association does not require the approval of the company court, in fact, as of the date when the instrument of constitution is executed in a notarized document or countersigned by a lawyer or bar association legal counsel, the business association may operate as the pre-company of the business association. A memorandum of association is concluded if signed by the parties, failure to execute in a notarized document or countersign by a lawyer or bar association legal counsel is an issue of invalidity. Registration by the company court is therefore not necessary for the formation of the memorandum of association, but for the formation of the company. If registration of the business association is refused by final decision, or if the company withdraws its application for registration, the pre-company must terminate all operations effective immediately upon gaining knowledge thereof.

\section{III.4. Content of the Memorandum of Association}

Memorandums of association may vary according to the method of establishment, the number of participants in the foundation or the form of the business association, but with regard to their content, the Civil Code establishes generally applicable standards. Section 3:5 of the Act lists these general mandatory elements (not only for companies but for all legal entities), as opposed to the common rules for obligations and the general rules for contracts, where no similar listings are to be found.

With the conclusion of the memorandum of association and the establishment of the company, company relations are also established. Such is the corporate relationship between the company and its members or former members. The members also have a corporate relationship with each other. There is also a corporate relationship between the company and the senior executive, as well as between the company and a member of the supervisory board.

Subsection (1) of Section 3:92 of the Civil Code states, that in accordance with the instrument of constitution or under an agreement between the parties concerned, any dispute in the area of company law shall be settled by way of binding arbitration. The arbitration may therefore be stipulated by agreement of the parties to the dispute or by a provision in the memorandum of association. The first case is not a specialty compared to the rules of arbitration, as the arbitration contract is also defined in Subsection (1) of Section 8 of the Arbitration Act as an agreement of the parties (meaning the parties involved in the dispute and thus becoming the parties of the proceedings). In such a case, the rules of arbitration shall apply to the arbitration agreement.

If the arbitration procedure is stipulated in the memorandum of association, two specificities must be taken into account. On the one hand, this clause also 
affects parties who are not parties to the agreement. The company's memorandum of association is drawn up by the members of the company, so they can also agree on arbitration. This agreement is limited to the parties to the agreement only in the case of disputes in the area of company law relating to the members, but in other cases the arbitration agreement affects not only the members, which is not necessarily in full harmony with the general principles of arbitration. As long as the agreement of the members makes the company itself, as a separate entity from the members, subject to arbitration, it can still be said that the company means in fact all the members, and thus the members can naturally define the obligations of the company in the memorandum of association, but in the case of executive officers and supervisory board members, this argument would hardly hold up. In the case of such persons, it is more acceptable for them to be subject to arbitration by agreement of the members because, when they accept their office, they undertake to work in a company governed by the memorandum of association and, if that memorandum includes arbitration, this is also accepted by executive officers and members of the supervisory board as binding on them. ${ }^{8}$

\section{III.5. Amendment of Contracts}

Amendment to the memorandum of association also shows differences from the general rules. For example, the instrument of constitution of a pre-company may not be altered, other than for the purpose of compliance with any request made by the court of registry or the competent body of authorization [3:101. § (2) b].

Special rules will continue to apply to the amendment of the memorandum of association. For example, Subsection (1) of Section 3:168 of the Code Civil states, that the memorandum of association of private limited-liability companies need not be amended as a result of any transfer of business shares. However, pursuant to Subsection (5) of Section 3:108, during the period of suspension of membership rights, the instrument of constitution of any business association may not be amended. According to Subsection (1) of Section 6:191 of the Civil Code, the parties shall be entitled to amend the content of a contract. By comparison, any amendment to the instrument of constitution can be decided by the supreme body of the company as well [3:102. § (1)]. Pursuant to Subsection (1) of Section 6:63, which is applicable through Subsection (3) of Section 6:191, the amendment of contracts are concluded upon the mutual and congruent expression of the parties' intent. Conversely, if an amendment to the memorandum of association is decided by the supreme body of the company, there is no need for a mutual and congruent expression of the intent of the members.

${ }^{8}$ Lajos Vékás, Péter, Gárdos „Kommentár a Polgári Törvénykönyvről szóló 2013. évi V. törvényhez „, Budapest 2014. Commentary to Section 3:92. 
Exceptions to the latter rule are general and limited partnerships. In their case, according to Subsection (4) of Section 3:143, a resolution adopted by the unanimous vote of all members shall be required for any amendment of the memorandum of association. Subsection (5) states, that the amendment of the memorandum of association shall be signed by all members. Thus, in the case of limited partnerships, an amendment of the contract prescribed on the basis of Section 12 of the act regulating the transitional provisions regarding the Civil Code, requires the unanimous decision of all members, as well. However, it cannot be assessed as an abuse of rights if the member does not sign the amending contract, the court cannot replace the member's declaration of rights. As stated in the ministerial justification attached to the Civil Code: It is also correct in the spirit of the case law that judicial practice considers the possibility of abuse of rights to be excluded, e.g. in case of refusal to enter into a contract or in case of a contract amendment statement (BH2017.268.).

According to Péter Bodnár Miskolczi, there is no sufficient reason for different amendment rules for general and limited partnerships, than for other companies. If it is true for other companies that requiring consensus would impede the operation of the company, then this theorem should also be considered true in the case of general and limited partnerships. These types of companies typically have a smaller number of members and more frequent family and friendships between the members, but this does not rule out conflicts. According to Miskolczi, by the fact that the parties have created a new legal entity, they manage it in their capacity as members (rather than contractors), even if the company does not have a separate organization. The creators are not pushed into the background by the organization, but by the creation of the legal entity. Maintaining the viability of a company requires majority decision-making (as opposed to consensus) even if the decision is not made within a formalized organization. A consensus gives all parties a right of veto. This may have very detrimental consequences for the entity: failure to agree may paralyze the company (see, for example, the case above).

Any amendment that would harm the rights of some members or make their status more onerous shall be decided by all members unanimously, as well [3:102. $\S(3)]$. For example, a restriction on the transfer of a share adversely affects the rights of the shareholder, so an amendment to the memorandum of association to that effect requires the unanimous resolution of all shareholders (BDT2017. 3666). However, Subsection (3) of Section 3:102 of the Civil Code provides for the unanimous decision of all members only in the event that an amendment to the memorandum of association would harm the rights of some members or make their status more onerous. Thus, for example, the conversion of shares into dematerialized shares, which incurs an account opening fee, is not linked to the amendment of the memorandum of association (PJD2018. 35). 
Otherwise, any amendment to the instrument of constitution, if done by means other by contract, shall be decided by the supreme body of the company by at least a three-quarters majority, and the supreme body may change the business association's corporate name, registered office, places of business and branches, and the activities of the business association other than its principle activity, by simple majority.

\section{III.6. Transfer of the Company Share}

The Civil Code allows the transfer of the company share, but only with certain restrictions. The latter operates in a similar way to a transfer of a contract, where the consent of the party remaining in the contract is required for the transfer of all the rights and obligations of the party withdrawing from the contract to the party entering into the contract. This consent is required by the Civil Code in several places when the company share is transferred, as well. And in some cases, it explicitly prohibits the transfer. For example, changes in the persons of the members of the pre-company are allowed only if expressly permitted by law [3:101. $\S(2)$ a)]. And, as the main rule, business shares may be transferred to third persons only if the member concerned has paid up his capital contribution in full [3:167. $\S(1)]$. An additional limitation is that the right to acquire a business share offered for sale in exchange for money is accrued to other members, the company, or a person designated by the company, in this order, according to the provisions on the right of preemption [3:167 $\S(2)]$. It is also possible, that the company's consent is required under the memorandum of association for the transfer of a business share to a third party buyer [3:167. $\S(6)]$. A limited company can also restrict the transfer of shares in its articles of association, or render the transfer of shares subject to the company's approval [3:219. § (1)].

The legal effects of the transfer of a share are similar to the legal effects of a transfer of a contract: the transferor's rights and obligations arising from the membership are transferred to the acquirer of the share. However, the other members of the company are not parties to the share transfer agreement, so the party acquiring the business share shall notify the company within eight days thereof. The notice, in addition to the fact of acquiring the business share, shall also contain a statement that the party acquiring the business share acknowledges the provisions of the memorandum of association as binding [3:168. § (2)]. A change in the person of a member stemming from the transfer of a business share shall take effect in respect of the company from the date when notified; the rights and obligations arising out of or in connection with membership shall accrue to the new holder of the business share from the date of notification, irrespective of registration [3:169. § (2)].

Under the general rules of contracts, it would be incomprehensible to acquire one's own share. A company may not exercise membership rights in connection 
with its own business shares; such business shares shall be disregarded for the purposes of quorum requirements. Within a period of one year following the purchase thereof, the company shall alienate the business shares acquired for consideration or shall convey them to the members in the percentage of their capital contributions, without compensation, or shall withdraw such business shares pursuant to the rules of capital reduction.

Nor can be interpreted on the basis of the general rules of contracts the obligations of the owner of a qualifying holding pursuant to Section 3:324 of the Civil Code. Within a sixty-day preclusive period reckoned from the date of notification of the acquisition of a qualifying holding, any member (shareholder) of the company may request that his shares be purchased by the owner of the qualifying holding. The latter provision means a contractual obligation for the owner of a qualifying holding. In accordance with the principle of freedom of contract, our law is only very narrowly aware of the obligation to enter into a contract based on law.

The transfer of the shares in general and limited companies is not prohibited in an absolute sense, the Civil Code only wants to ensure that the requirements arising from the nature of personal association will also apply in the case of a transfer. Technically, these conditions are provided by law by stipulating a corresponding amendment to the articles of association in order for the transfer to take effect. As an amendment to the memorandums of association requires the unanimous decision of all members of these companies, essentially any member can veto the transfer, which will therefore only take effect if all members unanimously agree and amend the memorandum of association in accordance with the transfer agreement. It follows that the contract of assignment may be concluded as a contract that's entry into force will require an amendment to the memorandum of association. The same rule applies where a member transfers his share not to an outsider but to another member. In this case, prescribing the appropriate amendment of the memorandum of association does not mean to prevent the entry of an unknown new person, but to prevent the ownership ratios and balances originally established by the members from being upset by the transfer. It is conceivable that, even without a change in the identity of the members, the interests of the members may be affected if the transfer results in a concentration of shares, as a result of which those who do not acquire shares by the transfer may be in a weaker position. ${ }^{9}$

\section{III.7. Change in the Number of the Contracting Parties}

Contrary to the general rules of contracts, in the case of memorandums of association, the Civil Code regulates the cases of increase in the number of contracting parties. There are several ways to this, which vary from company to company. The most common case is when one or more new contracting parties join the

${ }^{9}$ Ibid, Commentary to Section 3:148. 
previous contracting parties (members) in the memorandum of association. But it is also conceivable, for example, due to the division of the business share, that a contracting party (member) is replaced by several people at the same time. An increase in share capital may also result in an increase in the number of members.

According to points c) and d) of Section 6:3 of the Civil Code, the death or the termination without succession of the debtor or the creditor also results in the termination of the obligation in certain cases. The parties to the memorandum of association are in a position of both obligor and obligee, but their death or termination without a successor will result in the termination of the company in cases other than the above. However, a decrease in membership alone does not result in the dissolution of the company.

Section 7:1 of the Civil Code states that the estate of a person shall devolve upon an heir in its entirety after the testator's death. The estate, with certain exceptions, includes all the active and passive assets of the testator. However, in order to inherit the company share, the Civil Code also contains special provisions.

Pursuant to Section 3:149, the heir of a member who has died, or the successor of a member that has ceased to exist, can join the partnership as a member only based on an agreement with other members of the partnership. That is why an application for registration of a change of membership submitted after the time limitation stipulated in Subsection (1) of Section 3:152 of the Civil Code shall be rejected, since the general partnership is terminated without successor (BH2019. 53). The heir or successor shall not be required to provide capital contribution upon gaining membership.

Due to Section 3:155 of the Civil Code the above is also true for the limited partnership, so the fact that the heir acquires the estate ipso jure upon the death of the testator does not mean that the heir of the deceased member automatically becomes a member of the limited partnership. It requires the agreement of the heir and the other members and the amendment of the memorandum of association. The lack of proof of inheritance quality alone does not preclude an agreement and an amendment to the memorandum of association. The existence of an internal member and an external member is a conceptual feature of a limited partnership, the termination of any member position results in the termination of the limited partnership by the force of law. This legal consequence does not apply if the members amend the memorandum of association accordingly within six months and notify it to the court of registration. The six-month period prescribed for the notification of the restoration of the conditions for operating as a limited company is preclusive.

Subsection (2) of Section 3:170 of the Civil Codes states relating to private limited-liability partnerships, that the managing director may refuse to register the heir or the successor if the persons authorized under the memorandum of association provide a statement on the acquisition of the business share according 
to the conditions laid down in the memorandum of association within a preclusive period of thirty days from the date of the heir's or successor's application for registration taking effect, and if they pay the market value of the business share to the heir or successor. Any clause of the memorandum of association to provide a time limit longer than thirty days shall be null and void.

Pursuant to Subsection (3) of Section 3:237 of the Civil Code, in the event of death of the holder of employee shares, the heir of the employee may transfer such employee shares before the first general meeting held after a period of six months:

a) following the date of death of the testator, if no probate proceeding is held;

b) following the operative date of the grant of probate adopted in probate proceedings with full effect;

c) following the date when the judgment of the court becomes final, in the event of inheritance proceedings.

According to Subsection (4), if the former employee, or the heir, failed to dispose of the employee share, respectively, as provided for in Subsection (2) or within the time limit prescribed, the limited company may adopt a decision during the general meeting on the closure of the time limit for the withdrawal of the employee shares in question, or to sell the employee shares converted into another type of share. In that case, former employees or their heirs shall be entitled to the nominal value of their shares, payable within thirty days from the date of withdrawal or transfer of the shares in question.

Cases of a decrease in the number of members include when the number of members decreases because of their decision. For example, in the case of a general partnership, the member may terminate his membership. In the case of a private limited liability company, the number of members is reduced if, for example, two members transfer their shares to the same person.

The reduction in the number of members may also occur at the discretion of the company. An example of this is when the supreme body decides to involve the business share.

The number of members may also decrease due to the force of law. Thus, pursuant to Subsection (2) of Section 3:98 of the Civil Code, in the event of non-compliance within the thirty-day time limit, the membership of the member who failed to provide the capital contribution shall be terminated on the day following the expiration of such time limit.

Contrary to the general rules of contracts, in the case of companies, not only the contracting party (member) but also a third party may exercise the right of termination of the member. Thus, according to Section 3:140 of the Civil Code, if a creditor files to have the member's share in a general partnership attached, he shall be entitled to exercise the member's right of withdrawal.

In the context of the decrease in the number of members, we must also talk about the institution of expulsion of members. The general rules of contracts do 
not entitle the court to exclude a contracting party from the contract. However, a member of a business association may be excluded from the business association by court ruling based on a claim launched by the business association against such member, if the continued membership of the person in question would seriously jeopardize the business association's objective. Membership shall terminate upon the member's exclusion.

\section{III.8. Fulfillment of the Memorandum of Association}

It is also worth examining the fulfillment of the memorandum of association in accordance with the provisions of the Civil Code in its Sixth Book concerning the performance of the obligation and the contract.

Subsection (1) of Section 6:44 of the Act states, that the place of settlement of a monetary debt shall be the creditor's place of business at the time when the obligation was constituted, or, failing this the creditor's registered office. If the debtor settles the monetary debt by means other than cash payment, the place of settlement of the monetary debt shall be the place of business of the creditor's payment service provider at the time when the obligation was constituted, or, failing this, the bank's registered address. Pursuant to Subsection (5) of Section 30 of the Companies Act, unless otherwise prescribed by law, in company registration proceedings a statement by the managing director fixed in an authentic instrument countersigned by an attorney or bar association legal counsel or drawn up by a notary public may be accepted in accordance with this Act to verify payment of capital contribution; the managing director shall open a bank account for the company within eight days following registration and deposit the portion of that cash contribution that has not been used during the operation of the company before the opening of the account.

The latter rule is special to the provisions of the Civil Code relating to the place of settlement of a monetary debt. In the case of cash payments, the cash contribution must be paid into the company's treasury, which will be paid by the executive to one of the current accounts opened, or paid by the members themselves to one of the unregistered company's current accounts, or transferred to any account, because at the time of the occurrence of the obligation (conclusion and countersigning of the memorandum of association), the company did not yet have a current account, so the location or registered office of the bank managing it cannot be interpreted. Thus, in order to fulfill the financial contribution, Section 6:44 of the Civil Code is not applicable.

Section 6:128 of the Civil Code states, that on the delivery date either party may demand from the other party the performance of services which are due if he offers to perform his own service simultaneously. The law is therefore based 
on the principle of simultaneous performance in the case of remunerated contracts involving a bilateral service. The essence of simultaneous performance - unlike in the Civil Code from 1959 - is not given by the fact that it does not have to be performed until the other party offers its service [Subsection (1) of Section 281 of the old Civil Code], but that performance cannot be demanded from the other party until the party has performed or offered its own service. However, in the case of a company, it is not the other members but the management that calls on the member who did not provide his contribution stipulated in the memorandum of association by the required date to perform (§ 3:98).

Pursuant to Subsection (1) of Section 6:49 of the Act, the debtor shall be entitled to settle his debt also by way of setting off his overdue pecuniary claim against his monetary debt by means of a legal statement made out to the creditor. It would be difficult to find a specific legal basis for a position that a member should not fulfill his obligation to make a financial contribution by setting of his overdue claim against the company against his monetary debt by means of a legal statement made out to the company, as both the Civil Code and other Acts contain the prohibitions relating set-offs, however, there is no such prohibition in relation to monetary contributions by the members. Failing this, the rules of set-off may also be applied in connection with the payment of the financial contribution of the members.

If, upon commencement of dissolution or upon an order of liquidation, the initial capital of the private limited-liability company has not yet been paid up in full, the receiver in charge of the dissolution proceedings or the liquidator shall have the right to make outstanding payments due with immediate effect, and to order the performance thereof by the members, if this is necessary in order to satisfy the debts of the company [3:207. § (3)]. However, even then, the member may exercise the possibility of set-off. A limitation of setting of is, however, that in a liquidation proceeding, with regard to the debtor's claims, right of setoff may be exercised only with respect to such creditor's claims which have been registered by the liquidator as acknowledged and have not been assigned subsequent to the date when the court received the petition for opening liquidation proceedings, or, if the claim has occurred at a later date, subsequent to its occurrence [Insolvency Act 36. § (1)].

\section{III.9. Breach of the Memorandum of Association}

Infringement of the memorandum of association is also subject to different rules than the general rules on breach of contract. Of course, it is also true of the memorandum of association that a breach of any obligation under the contract means a breach of it, but this has special legal consequences. The most common case of breach of the memorandum of association is the non-performance of the agreed financial contribution. But it can also be the failure to fulfill the additional payment or the ancillary service obligation. 
It has already been mentioned that, after the thirty-day deadline set by the management, the membership of the member who does not make his financial contribution ends on the day following the expiry of the deadline. The right to demand performance is therefore limited here. This is a mandatory rule of the Civil Code. The company may have at most room for maneuver that the management „refrains" from sending the summons, so the thirty-day period cannot begin either. Members who do not agree with this solution may initiate a claim against the member (3:105. §).

Point b) of Subsection (2) of Section 6:154 of the Act also regulates the ineffective additional time limit for delays, but here there is still only a possibility for the right holder to terminate the contract by withdrawal. The additional period is not set by the company, it is thirty days by the force of law, which is also communicated to the member by the management, not by the company.

The issue of defective performance is also different in the case of memorandums of association. In fact, the performance of the member is considered to be defective if the value of the non-monetary contribution at the time of transfer does not reach the value indicated in the memorandum of association, as in this case the service does not meet the quality requirements set out in the memorandum of association. In this case, the company may demand payment of the difference from the person having provided the asset contribution within five years from the date of transfer [3:10. § (3)]. We already mentioned Section 3:105 of the Act, which of course also provides for the possibility that if the supreme body of the company rejects or has not submitted a resolution to enforce the company's claim against the member for the payment of the difference, the claim can be filed by the members with five percent of the voting rights within 30 days of the meeting, and they may assert the benefit of the company on behalf of the company. This is also true of the claims regulated in Subsection (2) of Section 3:99 of the Civil Code, which can also be enforced against those members who, despite their knowledge, have accepted the non-monetary property contribution of a member with a value exceeding the value at the time of service. However, member(s) without five percent of the vote may not bring such an action alone. Members with the appropriate number of votes may also file a lawsuit on behalf of the company only if a general meeting held within 30 days prior to the filing of the claim has been duly convened and the motion has been duly filed (BDT2011. 2520). In the event that the management does not comply with the provisions of the motion of the minority members to convene the supreme body, the meeting of the supreme body shall be convened by the court of registration according to Subsection (1) of Section 3:103 of the Civil Code or it shall authorize the petitioner members to convene the meeting. In the event of non-performance of the non-monetary contribution, the member will be called up by the management and, in the event of failure perform, the membership will be terminated. 
Non- or non-contractual performance of the property contribution may also have other legal consequences (for example action for damages).

Subsection (2) Section 3:98 of the Civil Code states, that the former member shall be held liable for damages caused to the business association by virtue of his failure to provide the contribution in accordance with the provisions on liability for damages for loss caused by non-performance of an obligation. Thus, if the company can prove that the damage suffered was caused by the non-payment of the property contribution, it will be very difficult for the member to exonerate himself from liability. Failure to pay the property contribution shall also be deemed to have occurred if the former member has only partially fulfilled his or her due obligation. The act speaks of the former member, because his membership had already been terminated by that time in view of the unsuccessful call of the management within a period of thirty days. However, this claim for damages cannot be enforced in parallel with Section 3:162 of the Civil Code, which covers the obligation to settle the debts of the company up to the amount of the unpaid financial contribution of the member, because the latter settlement applies only to the persons who are still members. This obligation is enforced not by the company but by the creditors, and not only if the member has not yet made their due contribution, but also if he has not yet made their pecuniary contribution because the memorandum of association set a later deadline.

Subsection (3) of Section 3:98 of the Civil Code states that any provision of the instrument of constitution which provides more lenient sanctions than what is prescribed in this Act upon members for failure to provide the capital contribution shall be null and void. It may be questioned whether a member gets a more lenient sanction if he is required to pay a contribution to the company instead of terminating his membership? It is unlikely, because if he is able to make a contribution, he will obviously do so if he does not want his membership to end. In such a case, the company will also be entitled to default interest due to the late payment of the contribution. However, withdrawal from the contract, as a general legal consequence of the debtor's delay, cannot be enforced by the company in such a case either.

I have already referred to the rule for private limited liability companies, according to which, if upon commencement of dissolution or upon an order of liquidation, the initial capital of the private limited-liability company has not yet been paid up in full, the receiver in charge of the dissolution proceedings or the liquidator shall have the right to make outstanding payments due with immediate effect, and to order the performance thereof by the members, if this is necessary in order to satisfy the debts of the company. In such a case, the member is obliged to fulfill his / her payment obligation and the rule regarding the additional period of 30 days and termination of membership does not apply.

Subsection (2) of Section 3:99 of the Civil Code states, that members who were knowledgeable about, and consented to, a non-monetary contribution that a 
member has provided at a value higher than what it was worth at the time when provided shall, together with the person providing it, be subject to joint and several liability toward the company in accordance with the provisions on liability for damages for loss caused by non-performance of an obligation. In my view, not the rules on damages should apply to members involved in the overvaluation of contributions. The obligation to make a financial contribution is incumbent on the members, whether or not they cause damage to the company. If a member accepts his non-monetary contribution in excess of the value at the time of service, this means that he has not fulfilled his contribution, but this also required other members to participate in the revaluation of the contribution. Therefore, in my opinion, it would be more appropriate to formulate a rule according to which members who have accepted a non-monetary contribution of a member with a value exceeding the value at the time of service are obliged to pay the difference jointly with the non-monetary contributor. In this case, it would also not be necessary to examine whether the non-monetary contribution was accepted by members „despite their knowledge" with a value in excess of the value at the time of service, which would also encourage the latter to proceed more diligently.

The legal consequences of non-performance of personal involvement are interesting. Pursuant to Subsection (1) of Section 3:182 of the Civil Code, a company may enforce a claim against a member for failure to provide personal assistance only if this is permitted by the memorandum of association. And if there is no such clause in the memorandum of association, the company is not subject to Subsection 6:138, which would give the company the right to demand performance. Obviously, the other legal consequences of a breach of contract are not applicable either, unless expressly provided for in the memorandum of association. Therefore, members belonging to a minority may also initiate the enforcement of a claim against the member who fails to provide personal assistance only if the enforcement of the claim is permitted by the memorandum of association. In the absence of this, liability for intentional breach of contract is also excluded by the force of law. It is important, however, that personal assistance does not qualify as an ancillary service if an employment contract or other (for example agency) legal relationship has been established between the limited liability company and its member (GK-MK No. 1).

And what is the legal consequence of a breach of the memorandum of association by the company? The latter is also an interesting issue because the company is not a contracting party, yet it can commit a breach of contract. As members also have rights against the company under the memorandum of association, they may be harmed in relation to them. In the event of a breach of the memorandum of association, the harmed member is entitled to demand the performance of the service. The legal consequences of a breach of contract are here, of course, also specific to the general rules of breach of contract. 


\section{III.10. The Rule on Termination of Obligations and Contracts in Case of Memorandums of Association}

Upon termination of the memorandum of association (the company), Section $6: 3$ of the Civil Code is not applicable as there are special rules for the dissolution of companies. Thus, the performance of the service cannot be interpreted as a termination circumstance either, as the members and the company are (or can be) constantly burdened by services against each other. However, the fulfillment of these does not terminate the membership relationship or the company. Only the non-performance of certain services can lead to their termination.

In the case of companies, it cannot happen that the same person becomes the obligee and the obligor, as the only member of the company can never be the company itself, as a one-person private limited liability company can't acquire its own business share, and a one-person limited company cannot acquire its own shares. The general partnership cannot be a member of itself even on a temporary basis, since according to Subsection (2) of Section 3:90 of the Civil Code he may not be an unlimited liability member of a company. As a result of the same rule, limited partnerships cannot be temporary members of their own. The death or termination of the members without a successor can only in case of general and limited partnerships lead in some cases to the dissolution of the company. The members may agree to dissolve the company, but in such a case, in addition, a decision of the court to delete the company after the liquidation procedure has been completed is required. It is important that members do not have the option to terminate the memorandum of association. Only the company can be dissolved, which must be followed by the liquidation procedure. The termination of contracts is, of course, never followed by any procedure for terminating property relations. This is self-evident, since, unlike the memorandum of association, the former do not create a legal entity with its own assets.

Section 6:3 of the Civil Code therefore does not play a role in connection with the dissolution of companies. The general rules for the dissolution of legal persons without legal successors are laid down in Section 3:48 of the Act, supplemented by special provisions governing each type of company. Termination with succession cannot be interpreted in the context of contracts either.

Under the general provisions on contracts the Civil Code states, that the parties may terminate a contract by mutual consent for future purposes, or may cancel the contract with retroactive effect to the date when it was concluded, and if any person who has the right of withdrawal or avoidance on the strength of law or on the basis of a contract may terminate the contract by making a statement to the other party. Regarding the termination of the memorandum of association, the Civil Code does not contain any provisions, but instead regulates the termination of the membership of the parties to the contract or of the company itself, which 
may also take place through unilateral and multilateral legal declarations, but there is no place for retroactive termination.

Thus, the Civil Code regulates, on the one hand, the termination of a member's membership, which, however, never results in the termination of the memorandum of association. The five cases of termination of a member's membership of a general or limited partnership are regulated in Section 3:146. These are supplemented by Section 3:140, which contains the right of termination of the member's creditor. The membership of a member of a business association may also be terminated by the court if by its decision the member is excluded from the company. The withdrawal of the business share also results in the termination of the membership of the owner of the business share. The membership of the member may also be terminated due to the non-payment of his contribution or the additional payment.

The way to end the membership with a unilateral declaration of rights is to terminate the membership. A member of a general or limited partnership may terminate his membership in writing with three months' notice. In the case of a company established for an indefinite period, the exclusion of this right is null and void - similarly to the regulation of Subsection (3) Section 6:123 of the Civil Code. However, according to Subsection (1) of Section 3:147, not only the exclusion of the right of termination, but - contrary to Subsection (3) of Section 6:213 - its restriction is also null and void. It also follows from the above that a member may, as a general rule, terminate his membership in the case of a company established for a definite period of time. In the case regulated is Section 3:140, the creditor of the member also has the right of termination.

Only the members of general and limited partnerships have the right of termination. The members of private limited-liability companies and limited companies may not exercise such a right.

The notice period is three months according to the Civil Code. However, the law does not provide for a period of notice in the event that a member terminates his membership if any other member of the partnership is engaged in a serious breach of the memorandum of association or in any conduct which seriously endangers cooperation with such member or the achievement of the purpose of the partnership [3:147. § (2)]. According to the decision published as VB1999.5.2., if a member of a limited partnership terminates his membership with immediate effect, even though its legal conditions are not met, the immediate termination cannot be considered as an ordinary termination.

Subsection (3) of Section 3:147 of the Civil Code states, that the partnership may bring action for the annulment of the termination of membership within a preclusive period of fifteen days from the effective date of the notice. We do not find such a rule amongst the general rules of contracts. This means that, in the case of other contracts, in the absence of a special rule, the rules on the invalidity 
of contracts must be properly applied to the invalidity of the termination. Thus, in the case of a challengeable termination, even no action is necessary, since pursuant to Subsection (3) of Section 6:89 of the Act, the right of appeal may also be exercised by a declaration of rights addressed to the other party.

In the event of termination of the membership, the company is obliged to settle accounts with the former member. Pursuant to Subsection (3) of Section 3:150 of the Act, the rules on settlement contain mandatory or claudically mandatory provisions. In the case of other contracts, it is not typical for the law to contain the method of settlement in a detailed manner, it is left to the contracting parties how they want to settle their property relations during the termination of the legal relationship between them.

Subsection (1) of Section 132/A of the Act on Judicial Enforcement states, that if the judgment debtor holds any interest in a general or limited partnership, the bailiff shall notify the judgment creditor that he is entitled to exercise the right of termination that is customarily due to the member. When the judgment creditor has provided a statement on termination to the bailiff, the bailiff shall convey it to the business association and shall concurrently seize the judgment debtor's claim that is due from the business association for termination of his membership (Sections 110-113). Pursuant to Subsection (2) settlement shall have no effect on the judgment debtor's liability for the company's debts, as prescribed by law. The judgment creditor shall not be held liable for the company's debts even if settlement is effected.

According to point a) of Section 3:146 of the Civil Code, in the case of general and limited partnerships, the membership can also be terminated by mutual agreement of the members. For other forms of companies, such a possibility is also not provided by law. In case of mutual agreement, the company is also obliged to settle with the former member.

The member's membership is also terminated in the event of expulsion. A member of a company may be expelled from the company by a court (arbitration) decision on the basis of an action brought by the company against the member concerned if his or her stay in the company would seriously jeopardize the achievement of the company's objectives. Membership exclusion is a legal institution for the protection of the interests of the company, which provides an opportunity to terminate the membership of a member who is unable to cooperate with the company, seriously jeopardizes the achievement of the company's goal, and exhibits serious anti-company behavior. For exclusion, no disadvantage or damage to interests must actually occur, it is sufficient if the member's stay in the company seriously jeopardizes the achievement of the company's goals (PJD2018.18.). The exclusion of members can only be based on the conduct of the members that poses a real and serious threat to the future operation of the company (BDT2019. 61.). It is important that this is not a special case of termination of the memorandum 
of association by a court, as the court does not terminate the contract, only the membership.

Exclusion from the company does not violate the constitutional right of the excluded member to free enterprise, because he still has the right to become an entrepreneur. The exclusion only results in the fact that he cannot exercise this right in the given company, with its members (PJD2016. 18.).

As a result of the involvement of the business share, the membership of the owner of the share is also terminated. It has already been mentioned, that the business share acquired by the company for consideration can only be retained by the company for one year from the date of the purchase. If the company does not dispose of it within one year, it is obliged to transfer it to the members in proportion to their core deposits free of charge or to do the involvement using the rules of the share capital reduction. If a business share is involved, the share capital must be reduced by the amount of the core deposit on which the business share is based.

Thus, while the general rules of contracts of the Civil Code provide that the parties may terminate a contract by mutual consent for future purposes, or may cancel the contract with retroactive effect to the date when it was concluded, and if any person who has the right of withdrawal or avoidance on the strength of law or on the basis of a contract may terminate the contract by making a statement to the other party, we have seen that although the membership can be terminated by termination and mutual agreement in some cases, there is no possibility for a retroactive termination. Due to the irreversibility of the company law relationship, it can only be terminated for the future.

Subsection (3) of Section 33 of the Companies Act states, that applications for registration may be withdrawn before the resolution of the first instance is adopted, in which case the court of registry shall terminate the proceedings. If the application for registration of a company is withdrawn, the document containing the termination of the pre-company shall be attached. In this case, not the memorandum of association itself but the pre-company will be terminated. However, in the absence of registration, no new company is created here, so in my opinion, the termination of the pre-company can also be based on the contract terminating the memorandum of association. However, even in such a case, cancellation of the partnership is possible only if the pre-company has not been active, as the cancellation is retroactive and the services already provided are returned, which can only take place if the original conditions can be restored in nature. If the pre-company has been engaged in activities (has made legal declarations), it is not possible to restore the original conditions, so the implementation of the retroactive cancellation is not feasible. In such a case, it is only possible to draw up a termination contract, which will terminate the memorandum of association for the future. 
Nor does the dissolution of a company without a legal successor result in the termination of all obligations imposed on the company, since in such a case the claim arising from the obligation of the terminated company can be enforced against the former members of the company within five years of deregistration. If the liability of a member for the obligations of the business association was unlimited during the company's existence, his guarantee obligation shall also be unlimited and joint and several with other members for the liabilities of the terminated business association. Any debt arising between members shall be covered by and shared among the members consistent with their share in the distributed assets of the business association (Civil Code 3:137. §).

\section{REFERENCES}

Miskolczi Bodnár Péter, „A társasági szerződés sajátosságai a Ptk.-ban szabályozott szerződésekhez képest", Gazdaság és Jog 2001/7-8.

Sándor István, „A társasági jog története Nyugat-Európában” Budapest 2005.

Sárközy Tamás, „A magyar társasági jog Európában”, Budapest 2001.

Sárközy Tamás, „Gazdasági státuszjog”, Budapest 2007.

Schadl György, „A társaságok és a társasági jog előzményei a római jogban.”, Acta Univ. Sapientiae, Legal Studies, 2/2013.

Schadl György, „A társaságok és a társasági jog fontosabb dogmatikai kérdéseinek elemzése.", Szeged 2011.

Vékás Lajos, Gárdos Péter, „, Kommentár a Polgári Törvénykönyvhöz” Budapest 2014. 
Mā̄e И. Moxau

Универзитетет у Печују

Правни факулитети

mohai.mate@ajk.pte.hu

\section{Уговор о оснивању привредног друштва у светлу одредаба о уговорима мађарског Грађанског законика}

Сажетйак: Нови мађарски Грађански законик рейулище уіоворе о осни-

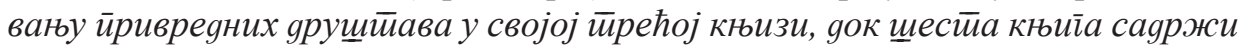
оgреgбе о (яруіим?) уїоворима. Уі̄овор о оснивану йрилично се разликује оg

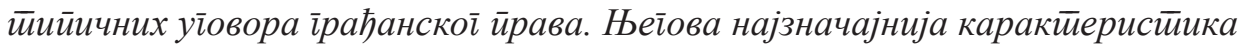

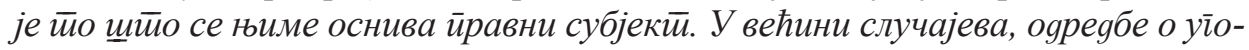
вору о осниваюу разликују се оg ояреgби о уіоворима саяржаним у Грађанском законику, а у закону не иоостиоји одреgба иррема којој би ове gруіе тиакође

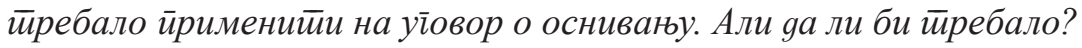

Кључне речи: уїовор о осниваюу, мађарски Грађански законик, мађарски

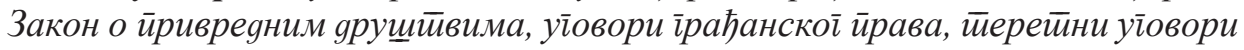

Датум пријема рада: 06.06.2020.

Датум прихватања рада: 08.06.2021. 